\title{
Genome Scan of European-American Schizophrenia Pedigrees: Results of the NIMH Genetics Initiative and Millennium Consortium
}

\author{
Stephen V. Faraone, ${ }^{1,2,3 *}$ Tara Matise, ${ }^{4}$ Dragan Svrakic, ${ }^{5}$ John Pepple, $^{1}$ Dolores Malaspina, ${ }^{6}$ \\ Brian Suarez, ${ }^{5}$ Carol Hampe, ${ }^{5}$ Christopher T. Zambuto, ${ }^{7}$ Karin Schmitt, ${ }^{7}$ Joanne Meyer, ${ }^{7}$ \\ Paul Markel, ${ }^{7}$ Hang Lee, ${ }^{1}$ Jill Harkavy-Friedman, ${ }^{6}$ Charles Kaufmann, ${ }^{6}$ C. Robert Cloninger, ${ }^{5}$ and \\ Ming T. Tsuang ${ }^{1,2,3,8}$ \\ ${ }^{1}$ Department of Psychiatry, Harvard Medical School at Massachusetts Mental Health Center, Boston, and \\ Brockton/West Roxbury VA Medical Center, Brockton, Massachusetts \\ ${ }^{2}$ Psychiatry Service, Massachusetts General Hospital, Boston, Massachusetts \\ ${ }^{3}$ Harvard Institute of Psychiatric Epidemiology and Genetics, Boston, Massachusetts \\ ${ }^{4}$ Laboratory of Statistical Genetics, Rockefeller University, New York, New York \\ ${ }^{5}$ Department of Psychiatry, Washington University School of Medicine, St. Louis, Missouri \\ ${ }^{6}$ Department of Psychiatry, Columbia University, New York, New York \\ ${ }^{7}$ Millennium Pharmaceuticals, Inc., Cambridge, Massachusetts \\ ${ }^{8}$ Department of Epidemiology, Harvard School of Public Health, Boston, Massachusetts
}

The Genetics Initiative of the National Institute of Mental Health (NIMH) was a multisite study that created a national repository of DNA from families informative for genetic linkage studies of schizophrenia, bipolar disorder, and Alzheimer's disease. The schizophrenia families were collected by three sites: Washington University, Harvard University, and Columbia University. This article, one in a series that describes the data collected for linkage analysis by the schizophrenia consortium, presents the results for the European-American sample. The European-American sample comprised 43 nuclear families and 146 subjects. Ninetysix of the family members were considered affected by virtue of having received a DSMIII-R diagnosis of schizophrenia $(\mathbf{N}=82)$ or schizoaffective disorder, depressed $(\mathbf{N}=14)$. The families contained a total of 50 independent sib-pairs. Using the significance threshold criteria suggested by Lander and Kruglyak [(1995): Nat Genet 241-247], no re-

Contract grant sponsor: National Institute of Mental Health; Contract grant numbers: 1 R01MH41874-01, 5 UO1MH46318, 1 R37MH43518, UO1MH46289, UO1MH46276, R01MH44292; Contract grant sponsor: Millennium Pharmaceuticals, Inc.; Contract grant sponsor: Wyeth-Ayerst Pharmaceuticals, Inc.; Contract grant sponsor: Division of Research Resources, U.S. Public Health Service; Contract grant number: 1 P41 RR03655.

*Correspondence to: Stephen V. Faraone, Ph.D., Harvard Medical School, 750 Washington St., Suite 255, South Easton, MA 02375 .

Received 30 September 1997; Revised 17 February 1998 gion showed statistically significant evidence for linkage; two markers on chromosome 10p showed statistical evidence suggestive of linkage using the criteria of Lander and Kruglyak [(1995): Nat Genet 241-247]: D10S1423 (nonparametric linkage (NPL) $\mathrm{Z}=3.4, P=.0004)$ and its neighbor, D10S582 (NPL $Z=3.2, P=$.0006). Am. J. Med. Genet. (Neuropsychiatr. Genet.) 81:290-295, 1998. ㅇ 1998 Wiley-Liss, Inc.

KEY WORDS: schizophrenia; linkage; NIMH Genetics Initiative

\section{INTRODUCTION}

This article is one in a series that describes the linkage data collected by the schizophrenia consortium. Cloninger et al. [this issue] describe the background of the project and its strategies for ascertainment, data collection, pedigree extension, diagnosis and data analysis. Kaufmann et al. [this issue] present the results for the African-American sample. We present the results for the European-American sample.

\section{Sample Description}

The European-American sample comprised 43 nuclear families and 146 subjects. Ninety-six of the family members were considered affected by virtue of having a DSM-III-R diagnosis of schizophrenia $(\mathrm{N}=$ 82 ) or schizoaffective disorder, depressed $(N=14)$. The families contained a total of 50 independent affected sib-pairs (calculated as number of affected sibs minus 1). Thirty-six families had 2 affected sibs, and seven 
families had 3 affected sibs. Table I breaks down the sample according to the number of sibs (including the affected sibs) and parents with DNA available. As Table I indicates, 14 of the affected sib-pairs had two parents available for genotyping, 19 had one parent available, and 10 had no parents available. Two of the sib-pairs were half-sibs. One of these had no parental DNA available, while the other had DNA available from the common parent.

Sixty-six percent of the affected subjects were male; they had a mean age of $43 \pm 14$ years. Their mean age at onset was $20.8 \pm 7.5$ years, and they had a mean educational level of $11.7 \pm 2.6$ years. Thirty-one percent of the unaffected subjects were male; they had a mean age of $66 \pm 10$ years. Their mean educational level of $11.2 \pm 3.4$ years.

\section{RESULTS}

The results are presented in Figure 1, which presents for each chromosome the multipoint nonparametric linkage (NPL) Z-scores computed by GENEHUNTER [Kruglyak et al., 1996] for each marker locus. According to Lander and Kruglyak [1995], highly significant evidence from a genome scan requires $P<$ 0.0000003 ; significant evidence from a genome scan requires $P<0.00002$; and suggestive evidence requires $P$ $<0.0007$.

In our analyses, no region showed statistically significant evidence for linkage, but two markers on chromosome 10p showed statistical evidence suggestive of linkage: D10S1423 (NPL Z $=3.4, P=0.0004$ ) and its neighbor, D10S582 (NPL Z $=3.2, P=0.0006$ ).

To facilitate the examination of the remaining small peaks in Figure 1, Table II summarizes the results for all markers with NPL scores $>1.5$ (these correspond to $P<0.06$ ). In creating Table II, our use of a threshold of 1.5 was arbitrary, yet provides a convenient means of summarizing our results.

Table II also shows genetic locations (in megabases from ptr) derived from the Genetic Location Data Base (http://cedar.genetics.soton.ac.uk/public_html/), along with estimates of the mean identity-by-descent sharing of marker alleles estimated by SIBPAL [S.A.G.E., 1994]. For markers not in the Genetic Location Data Base, locations were estimated from flanking markers in the database.

Because we did not have complete parental genotyp-

TABLE I. Distribution of Families by Number of Siblings and Parents Genotyped

\begin{tabular}{lcccc}
\hline \multirow{2}{*}{$\begin{array}{l}\text { Number of } \\
\text { siblings genotyped }\end{array}$} & \multicolumn{4}{c}{ Number of parents genotyped } \\
\cline { 2 - 5 } & 0 & 1 & 2 & Total \\
\hline 2 & $3^{\mathrm{a}}$ & $15^{\mathrm{b}}$ & 13 & 31 \\
3 & 6 & 4 & 1 & 11 \\
4 & 1 & 0 & 0 & 1 \\
5 & 0 & 0 & 0 & 0 \\
Total & 10 & 19 & 14 & 43 \\
\hline
\end{tabular}

a One family consists of a pair of half sibs.

${ }^{\mathrm{b}}$ One family constists of a pair of half-sibs plus their common parent. Note: Ninety-six family members were considered affected by virtue of having a DSM-III-R diagnosis of schizophrenia $(\mathrm{N}=82)$ or schizoaffective disorder, depressed $(\mathrm{N}=14)$. ing information for all families, it was necessary to estimate marker allele frequencies for the linkage analyses. To determine if the choice of allele frequencies had influenced the results, we computed the mean identityby-descent (IBD) sharing of marker alleles for the two chromosome 10 markers showing suggestive evidence for linkage, using three different estimates of the marker allele frequencies: 1$)$ the estimates, $P(\mathrm{i})$, taken from our sample; 2) $P(i)+.10$; and 3) $1 /$ the number of alleles at the marker locus). The results in Table III show that the IBD estimates did not vary much with either the choice of allele frequency estimate or the number of parents with DNA available.

\section{DISCUSSION}

Our genome scan of 50 European-American sib-pairs from the schizophrenia consortium of the NIMH Genetics Initiative found suggestive evidence for linkage to one region on chromosome $10 \mathrm{p}$, but no evidence of linkage elsewhere. Notably, we did not find linkage to the three regions that had been implicated by other investigators: 22q11-q13 [Pulver et al., 1994b; Schizophrenia Collaborative Linkage Group (Chromosome 22), 1996], 6p23 [Moises et al., 1995; Schwab et al., 1995; Straub et al., 1995], and 8p22-21 [Pulver et al., 1995; Kendler et al., 1996; Schizophrenia Linkage Collaborative Group for Chromosomes 3, 6, and 8, 1996]. We also did not show linkage to 6q13-q26, even though Cao et al. [1997] found linkage to this region using 69 affected sib-pair families from our larger set of pedigrees that included families of European-American, African-American, and other ethnic backgrounds. Notably, the $6 q$ linkage was observed in our genome scan of the African-American families of Kaufmann et al. [this issue].

That we did not confirm prior reports of linkage is consistent with other groups who did not find evidence for linkage to 22q11-q13 [Pulver et al., 1994a; Kalsi et al., 1995; Schizophrenia Collaborative Linkage Group (Chromosome 22), 1996], 6p23 [Wang et al., 1993; Antonarakis et al., 1995; Gurling et al., 1995; Mowry et al., 1995], and 8p22-21 [Kunugi et al., 1996]. As Suarez et al. [1994] reported, consistent replication of linkage findings is not expected under oligogenic inheritance. This fact, the fact that we did not test exactly the same markers used by other groups, and the low power of our sample to detect small effects, emphasize that our negative findings are not conclusive.

There are several reasons to be cautious in interpreting the suggestive linkage to $10 \mathrm{p}$ in our schizophrenia pedigrees. Most importantly, the three prior published reports that presented chromosome 10 linkage data did not implicate 10p. Coon et al. [1994b] ascertained nine pedigrees, each containing 3-5 cases of schizophrenia. They found no evidence for linkage to any of four markers in the region 10pter-p13. All of their markers excluded linkage (lod <-2.0) under an autosomal dominant model, and three excluded linkage under a recessive model. Moreover, our results from the AfricanAmerican sample of the NIMH Genetics Initiative [Kaufmann et al., this issue] and the genome screen of Moises et al. [1995] found no evidence for linkage to 

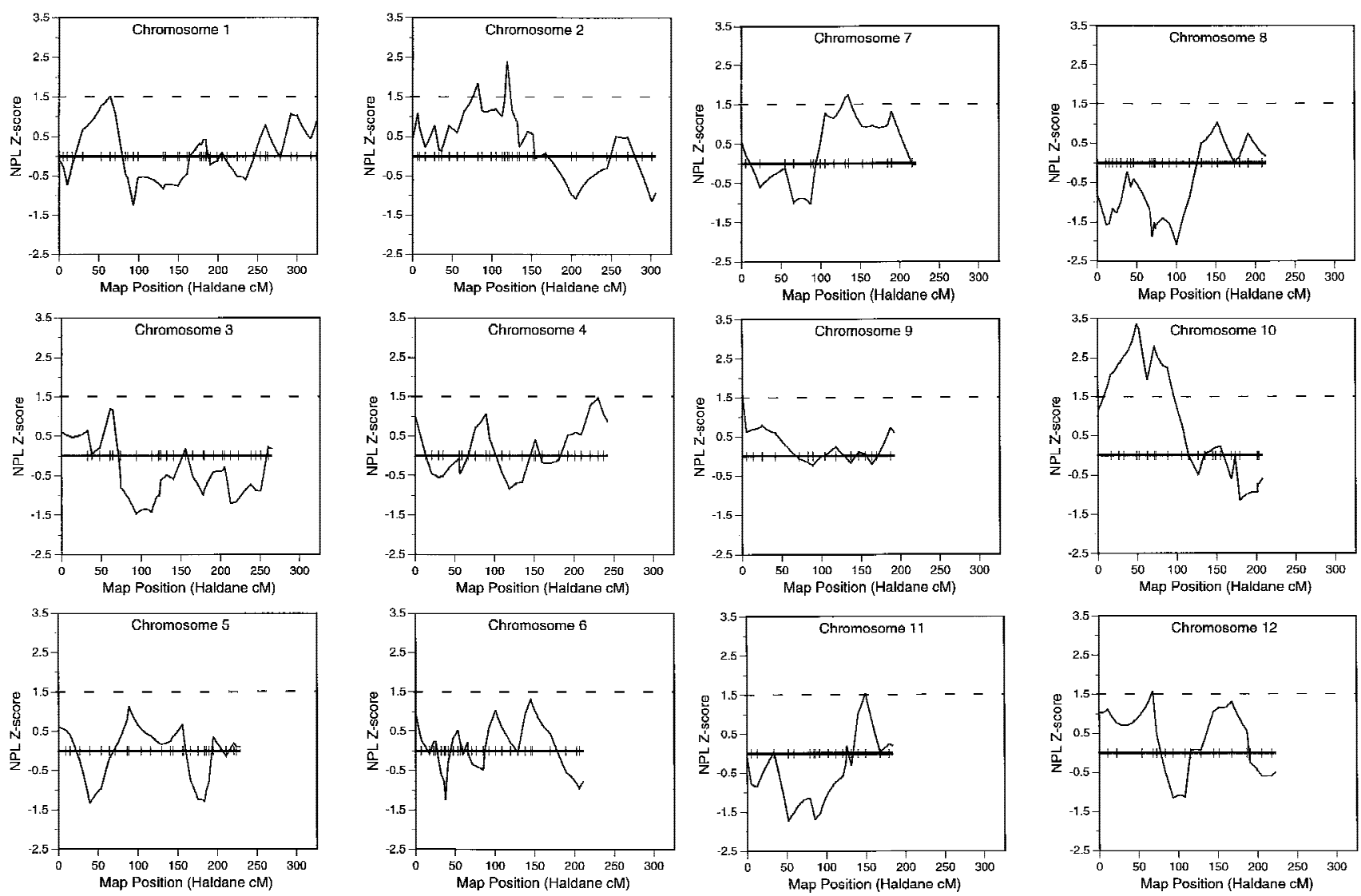

Fig. 1. Multipoint NPL Z-scores for European-American pedigrees.

$10 p$ or $10 q$ using 14 markers. Barr et al. [1994] found no evidence of linkage to three markers on chromosome $10 \mathrm{q}$, but did not evaluate linkage to 10p.

In contrast to these negative published findings, in an independent study, Straub et al. [1997] recently presented schizophrenia linkage data from 265 Irish pedigrees which implicate $10 p$ between D10S674 and D10S1426, which overlaps with the region implicated in this report. Their maximum multipoint heterogeneity lod score for this region was $1.91(P=$ 0.006 ), and their maximum multipoint nonparametric (NPL) score was $1.88(P=0.03)$, each occurring at D10S2443. Moreover, Wildenauer (personal communication) has had positive results in this region for D10S582 $(P=0.006)$ and D10S1423 $(P=0.029)$. There is also one cytogenetic study that implicates $10 \mathrm{p}$ in schizophrenia. Axelsson and Wahlström [1984] screened for chromosome aberrations in 134 consecutive patients with paranoid psychosis. One patient had an inversion on chromosome 10 [inv(10)(p12q21)].

The two 10p markers showing suggestive linkage (D10S1423 and D10S582) have not been precisely located on the cytogenetic map. According to the Genome Data Base (http://gdbwww.gdb.org/gdb/docs/ gdbhome.html), D10S1423 is in the region 10p14-p13 and D10S582 is in 10p13-p12. According to the Genetic Location Database (http://cedar.genetics.soton.ac.uk/ public_html/) [Collins et al., 1996], the most likely location for D10S582 is 10p13. We consulted Online
Mendelian Inheritance in Man (OMIM) (http:// www3.ncbi.nlm.nih.gov/Omim/) to determine what genes were in the regions implicated by these two markers.

According to OMIM, Daw et al. [1996] and Lipson et al. [1996] reported that deletions at 10p13-14 were associated with a rare form of velo-cardio-facial syndrome (VCFS). As noted by Pulver et al. [1994b], the more common form of VCFS is caused by microdeletions in the region $22 q 11$, which is in the vicinity of the region they had implicated in their linkage analysis of schizophrenia pedigrees. The relevance of VCFS is that some cases exhibit psychosis and other schizophrenia-like symptoms [Shprintzen et al., 1992]. Moreover, Karayiorgou et al. [1995] found two cases of 22q11 deletions among a series of 100 schizophrenic patients.

The region implicated by our linkage analyses includes the genes for the interleukin-2 receptor alpha chain (IL2RA, \{3.8\}, 10p15-p14) and interleukin-15 receptor alpha chain (IL15RA, \{7.6\}, 10p15-p14). Although these genes, which are involved in autoimmunity, have not been directly implicated in schizophrenia, it is of interest that a related gene (interleukin-2 receptor beta chain) on 22q13 showed evidence of linkage to schizophrenia in the study of Pulver et al. [1994b] and that of Coon et al. [1994a]. Although genetic association studies of IL2RB and schizophrenia have been negative [Nimgaonkar et al., 1995; Tatsumi et al., 1997], others have reported abnormalities in in- 
European-American Schizophrenia Pedigrees
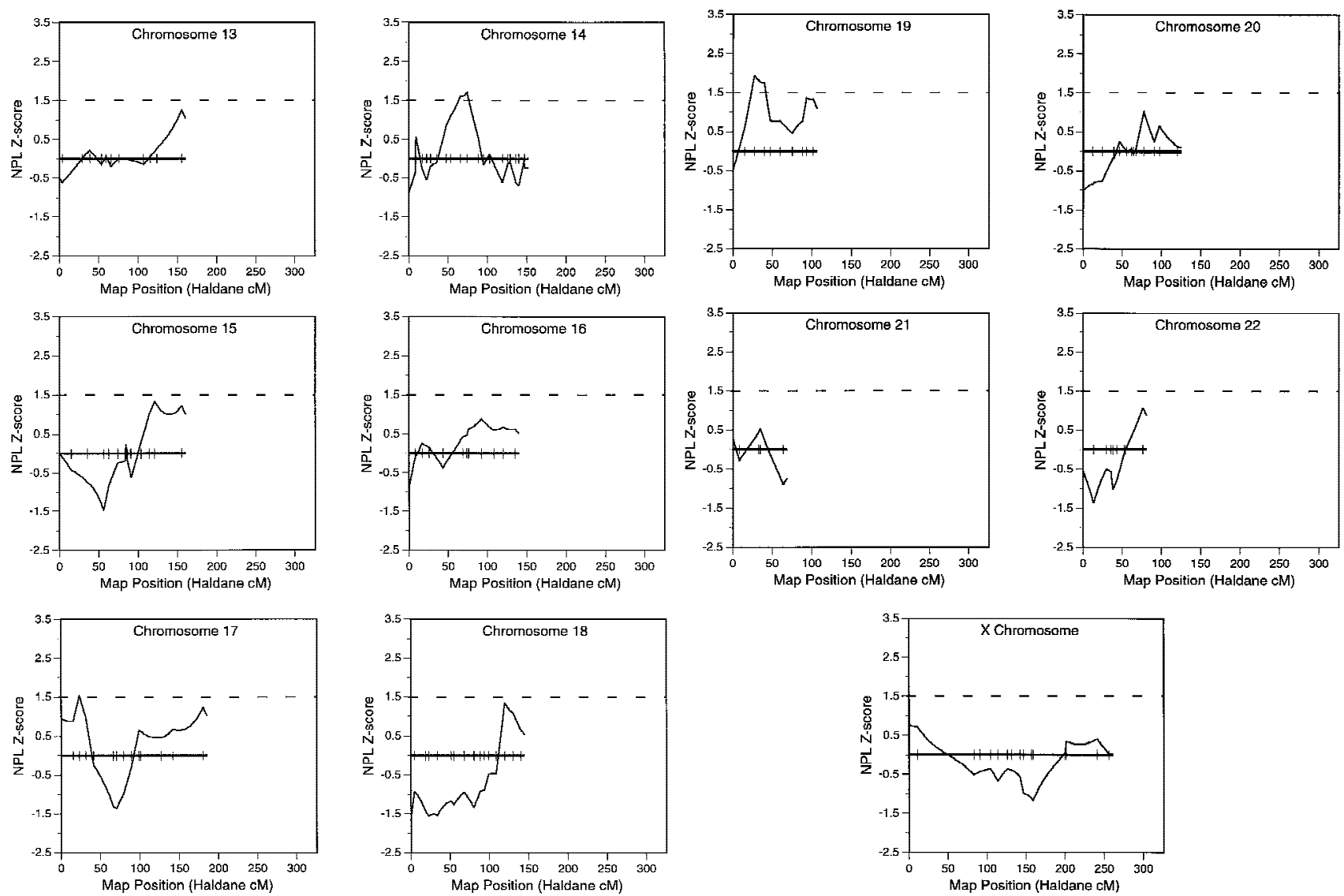

Fig. 1. (Continued).

TABLE II. Results for Markers With NPL Z-Scores Greater Than 1.5*

\begin{tabular}{|c|c|c|c|c|c|c|c|c|}
\hline Chromosome & Marker & $\begin{array}{l}\text { Marker } \\
\text { number }\end{array}$ & Location & Region & $\begin{array}{l}\text { Information } \\
\text { content }\end{array}$ & $\begin{array}{c}\text { NPL } \\
\text { Z-score }\end{array}$ & $P$ & $\begin{array}{c}\text { IBD } \\
\text { sharing }\end{array}$ \\
\hline 1 & D1S1622 & 7 & 32.5 & $1 \mathrm{p} 34.3$ & 0.59 & 1.52 & 0.07 & 0.58 \\
\hline 2 & $\mathrm{D} 2 \mathrm{~S} 441$ & 12 & 69.0 & $2 \mathrm{p} 14$ & 0.75 & 1.85 & 0.03 & 0.59 \\
\hline 2 & D2S293 & 18 & 105.9 & $2 \mathrm{q} 12$ & 0.79 & 2.41 & 0.008 & 0.63 \\
\hline 2 & D2S1893 & 18 & 106.6 & $2 q 12$ & 0.85 & 1.99 & 0.02 & 0.57 \\
\hline 7 & D7S821 & 12 & 104.5 & $7 q 21$ & 0.73 & 1.66 & 0.05 & 0.55 \\
\hline 7 & D7S1799 & 13 & 115.6 & $7 \mathrm{q} 31$ & 0.69 & 1.74 & 0.04 & 0.55 \\
\hline 9 & D9S288 & 1 & 3.0 & $9 \mathrm{p} 24$ & 0.71 & 1.70 & 0.05 & 0.54 \\
\hline 10 & D10S189 & 2 & 8.0 & $10 \mathrm{p} 15$ & 0.57 & 2.07 & 0.02 & 0.57 \\
\hline 10 & D10S1412 & 3 & $11.2^{\mathrm{a}}$ & $\mathrm{NA}$ & 0.68 & 2.35 & 0.01 & 0.56 \\
\hline 10 & D10S2325 & 4 & $13.4^{\mathrm{a}}$ & $10 \mathrm{p} 14$ & 0.73 & 2.54 & 0.006 & 0.56 \\
\hline 10 & D10S1423 & 5 & $18.5^{\mathrm{a}}$ & NA & 0.75 & 3.36 & 0.0004 & 0.61 \\
\hline 10 & D10S582 & 6 & 19.5 & $10 \mathrm{p} 13$ & 0.82 & 3.24 & 0.0006 & 0.63 \\
\hline 10 & D10S1426 & 7 & $34.1^{\mathrm{a}}$ & NA & 0.77 & 1.95 & 0.03 & 0.55 \\
\hline 10 & D10S604 & 8 & 47.1 & $10 \mathrm{q} 11.2$ & 0.72 & 2.79 & 0.003 & 0.64 \\
\hline 10 & D10S1220 & 9 & $50.1^{\mathrm{a}}$ & $10 q 11.2$ & 0.70 & 2.65 & 0.004 & 0.58 \\
\hline 10 & D10S1225 & 10 & $70.3^{\mathrm{a}}$ & $10 \mathrm{q} 21$ & 0.64 & 2.24 & 0.01 & 0.56 \\
\hline 11 & GATA64D0 & 18 & $128.4^{\mathrm{a}}$ & $10 q 23$ & 0.50 & 1.54 & 0.06 & 0.57 \\
\hline 12 & D12S1042 & 5 & 23.7 & $12 \mathrm{p} 11.2$ & 0.75 & 1.58 & 0.06 & 0.60 \\
\hline 14 & D14S592 & 10 & 58.1 & $14 q 22$ & 0.61 & 1.60 & 0.06 & 0.55 \\
\hline 14 & D14S588 & 11 & 66.5 & $14 q 24$ & 0.68 & 1.70 & 0.05 & 0.53 \\
\hline 17 & D17S796 & 3 & 8.4 & NA & 0.69 & 1.55 & 0.06 & 0.60 \\
\hline 19 & D19S714 & 3 & $29.3^{\mathrm{a}}$ & $17 \mathrm{p} 12$ & 0.76 & 1.94 & 0.03 & 0.54 \\
\hline 19 & D19S433 & 4 & 34.7 & $\mathrm{NA}$ & 0.73 & 1.75 & 0.04 & 0.53 \\
\hline
\end{tabular}

*NPL Z-scores computed with GENEHUNTER; mean IBD sharing computed with SIBPAIR; locations are in MB from pter (Genetic Location Data Base (http://cedar.genetics.soton.ac.uk/public_html/)) [Collins et al., 1996]; regions were derived from the NCBI Entez Genome Query (http:// www.ncbi.nlm.gov/cgi-bin/entrez/); NA, not available.

${ }^{a}$ Estimated location for markers not in database. 
TABLE III. Mean Identity-by-Descent Sharing of Marker Alleles for Chromosome 10 Markers*

\begin{tabular}{|c|c|c|c|c|c|c|c|c|}
\hline \multirow[b]{2}{*}{ Marker } & \multicolumn{4}{|c|}{ D10S1423, number of parents with DNA available } & \multicolumn{4}{|c|}{ D10S582, number of parents with DNA available } \\
\hline & Two & One & None & Total & Two & One & None & Total \\
\hline$P(\mathrm{i})$ & 0.60 & 0.63 & 0.57 & 0.61 & 0.62 & 0.67 & 0.57 & 0.63 \\
\hline$P(\mathrm{i})+.10$ & 0.60 & 0.65 & 0.60 & 0.62 & 0.62 & 0.70 & 0.59 & 0.65 \\
\hline $1 /$ no. of alleles & 0.60 & 0.68 & 0.66 & 0.66 & 0.62 & 0.72 & 0.63 & 0.67 \\
\hline
\end{tabular}

*Mean IBD computed by SIBPAL; $P(\mathrm{i})=$ marker allele frequencies estimated from the sample.

terleukin-2 production in the lymphocytes of schizophrenic patients [O'Donnell et al., 1996].

We also note that the GAD3 gene, which encodes a form of the enzyme glutamic acid decarboxylase, is located at 22q13 [Edelhoff et al., 1993]. This is another curious correspondence between $22 \mathrm{q}$ and $10 \mathrm{p}$, which harbors the GAD2gene $\{32.9\}$. GAD catalyzes the conversion of glutamic acid to gamma-aminobutyric acid (GABA), a major inhibitory neurotransmitter in the central nervous system (CNS). The GAD1 gene encodes the 65-kilodalton $(\mathrm{kD})$ form of GAD. In the CNS, GAD65 appears to be localized in nerve terminals, suggesting that it responds to short-term changes in the need for GABA [Martin and Rimvall, 1993]. Postmortem studies have found GAD65 mRNA messages in the suprachiasmatic nucleus [O'Hara et al., 1995; Gao and Moore, 1996a]; the anterior hypothalamic area [Gao and Moore, 1996b]; and in the sexually dimorphic nucleus of the preoptic area [Gao and Moore, 1996b]. Decreased brain levels of glutamic acid decarboxylase have been associated with schizophrenia in some studies [Bird et al., 1977; Akbarian et al., 1995], but not in others [Bennett et al., 1979; Hanada et al., 1987]. It is not known if the positive associations apply to the 65$\mathrm{kD}$ form.

For several reasons, it would be premature to draw any conclusions about candidate genes in the $10 \mathrm{p}$ region implicated by our results. Assuredly, our results call for replication by other investigators. Moreover, there are many genes in the broad region implicated by our results. For example, in the interval between D10S1423 and D10S582 (which showed the strongest signal for linkage), there are at least 36 mapped expressed sequence tags, most of which are unidentified transcripts (http://www.ncbi.nlm.nih.gov/ SCIENCE96/) [Hudson et al., 1995]. Thus, although our speculations about candidate genes may be useful for generating hypotheses and choosing markers for further studies, they are far from definitive.

\section{ACKNOWLEDGMENTS}

Preparation of this article was supported in part by National Institute of Mental Health grants 1 R01MH41874-01, 5 UO1MH46318, and 1 R37MH43518 (to M.T.T.), UO1MH46289 (to C.K.), UO1MH46276 (to C.R.C.), and R01MH44292 (to Dr. Jurg Ott and C.K.), and by contracts with Millennium Pharmaceuticals, Inc. (which is sponsored by Wyeth-Ayerst Pharmaceuticals, Inc.). Some of the results of this paper were obtained by using the program package S.A.G.E., which is supported by a U.S. Public Health Service Resource Grant (1 P41 RR03655) from the Division of Research Resources. The
National Institute of Mental Health Genetics Initiative for schizophrenia is a multisite study performed by three independent research teams in collaboration with staff from the National Institute of Mental Health (NIMH). The NIMH collaborators include David Shore, M.D., Debra Wynne, M.S.W., Steven O. Moldin, Ph.D., Darrell G. Kirch, M.D. (1989-1994), Kate A. Berg, Ph.D. (1990-1994), and Nancy E. Maestri, Ph.D. (19921994); the NIMH Senior Scientific Consultant is Darrel A. Regier, M.D., M.P.H. The principal investigators and co-investigators from the three sites are: at Harvard University (Boston, MA), Ming T. Tsuang, M.D., Ph.D., D.Sc., Stephen Faraone, Ph.D., and John Pepple, Ph.D.; at Washington University (St. Louis, MO), C. Robert Cloninger, M.D., Theodore Reich, M.D., and Dragan Svrakic, M.D.; and at Columbia University (New York, NY), Charles Kaufmann, M.D., Dolores Malaspina, M.D., and Jill Harkavy Friedman, Ph.D. Blood samples are sent to the NIMH Cell Repository at the Coriell Institute for Medical Research (Camden, NJ). Clinical data are stored in the NIMH Data Management Center at SRA Technologies, Inc. (Falls Church, VA).

\section{REFERENCES}

Akbarian S, Kim JJ, Potkin SG, Hagman JO, Tafazzoli A, Bunney WE Jr, Jones EG (1995): Gene expression for glutamic acid decarboxylase is reduced without loss of neurons in prefrontal cortex of schizophrenics. Arch Gen Psychiatry 52:258-266.

Antonarakis SE, Blouin J-L, Pulver AE, Wolyniec P, Lasseter VK, Nestadt G, Kasch L, Babb R, Kasazian HH, Dombroski B, Kimberland M, Ott J, Housman D, Karayiorgou M, MacLean CJ (1995): Schizophrenia susceptibility and chromosome 6p24-22. Nat Genet 11:235-236.

Axelsson R, Wahlström J (1984): Chromosome aberrations in patients with paranoid psychosis. Hereditas 100:29-31.

Barr CL, Kennedy JL, Pakstis AJ, Wetterberg L, Sjogren B, Bierut L, Wadelius C, Wahlstrom J, Martinsson T, Giuffra L, Gelernter J, Hallmayer J, Moises HW, Kurth J, Cavalli-Sforza LL, Kidd KK (1994): Progress in a genome scan for linkage in schizophrenia in a large Swedish kindred. Am J Med Genet 54:51-58.

Bennett JP Jr, Enna SJ, Bylund DB, Gillin JC, Wyatt RJ, Snyder SH (1979): Neurotransmitter receptors in frontal cortex of schizophrenics. Arch Gen Psychiatry 36:927-934.

Bird ED, Spokes EG, Barnes J, MacKay AV, Iversen LL, Shepherd M (1977): Increased brain dopamine and reduced glutamic acid decarboxylase and choline acetyl transferase activity in schizophrenia and related psychoses. Lancet 2:1157-1158.

Cao Q, Martinez M, Zhang J, Sanders AR, Badner JA, Cravchik A, Markey CJ, Beshah E, Guroff JJ, Maxwell ME, Kazuba DM, Whiten R, Goldin LR, Gershon ES, Gejman PV (1997): Suggestive evidence for a schizophrenia susceptibility locus on chromosome $6 \mathrm{q}$ and a confirmation in an independent series of pedigrees. Genomics 43:1-8.

Collins A, Frezal J, Teague J, Morton NE (1996): A metric map of humans: 23,500 loci in 850 bands. Proc Nat Acad Sci 93:14771-14775.

Coon H, Holik J, Hoff M, Reimherr F, Wender P, Freedman R, Byerley W (1994a): Analysis of chromosome 22 markers in 9 schizophrenia pedigrees. Am J Med Genet 54:72-79. 
Coon H, Jensen S, Holik J, Hoff M, Myles-Worlsey M, Reimherr F, Wender P, Waldo M, Freedman R, Leppert M, Byerley W (1994b): A genomic scan for genes predisposing to schizophrenia. Am J Med Genet 54:59 71.

Daw SCM, Taylor C, Kraman M, Call K, Mao J, Schuffenhauer S, Meitinger T, Lipson T, Goodship J, Scambler P (1996): A common region of $10 \mathrm{p}$ deleted in DiGeorge and velocardiofacial syndromes. Nat Genet 13:458-461.

Edelhoff S, Grubin CE, Karlsen AE, Adler DA, Foster D, Disteche CM, Lernmark A (1993): Mapping of glutamic acid decarboxylase (GAD) genes. Genomics 11:93-97.

Gao B, Moore RY (1996a): Glutamic acid decarboxylase message isoforms in human suprachiasmatic nucleus. J Biol Rhythms 11:172-179.

Gao B, Moore RY (1996b): The sexually dimorphic nucleus of the hypothalamus contains GABA neurons in rat and man. Brain Res 742:163171.

Gurling H, Kalsi G, Chen AH, Green M, Butler R, Read T, Murphy P, Curtis D, Sharma T, Petursson H, Brynjolfsson J (1995): Schizophrenia susceptibility and chromosome 6p24-22. Nat Genet 11:234-235.

Hanada S, Mita T, Nishino N, Tanaka C (1987): [3H]muscimol binding sites increased in autopsied brains of chronic schizophrenics. Life Sci 40:259-266.

Hudson TJ, Stein LD, Gerety SS, Ma J, Castle AB, Silva J, Slonim DK, Baptista R, Kruglyak L, Xu S-H, Hu X, Wu X, Vestergaard C, Wilson KM, Bae JS, Maitra S, Ganiatsas S, Evans CA, DeAngelis MM, Ingalls KA, Nahf RW, Horton LT Jr, Anderson MO, Collymore AJ, Ye W, Kouyoumjian V, Zemsteva IS, Tam J, Devin ER, Courtney DF, Renaud MT, Nguyen H, O'Connor TJ, Fizames C, Faure S, Gyapay G, Dib C, Morissette J, Orlin JB, Birren BW, Goodman N, Weissenbach J, Hawkins TL, Foote S, Page DC, Lander ES (1995): An STS-based map of the human genome. Science 270:1945-1954.

Kalsi G, Brynjolfsson J, Butler R, Sherrington R, Curtis D, Sigmundssonn T, Read T, Murphy T, Sharma T, Petursson H, Gurling HMD (1995): Linkage analysis of chromosome $22 q 12-13$ in a United Kingdom/ Icelandic sample of 23 multiplex schizophrenia families. Am J Med Genet 60:298-301.

Karayiorgou M, Morris MA, Morrows B, Shprintzen RJ, Goldberg R, Borrow J, Gos A, Nestadt G, Wolyniec PS, Lasseter VK, Eisen H, Childs B, Kazaian HH, Kucherlapati R, Antonarakis SE, Pulver AE, Housman DE (1995): Schizophrenia susceptibility associated with interstitial deletions of chromosome 22q11. Proc Nat Acad Sci USA 92:7612-7616.

Kendler KS, MacLean CJ, O’Neill FA, Burke J, Murphy P, Duke F, Shinkwin R, Easter SM, Webb BT, Zhange J, Walsh D, Straub RE (1996) Evidence for a schizophrenia vulnerability locus on chromosome $8 p$ in the Irish study of high-density schizophrenia families. Am J Psychiatry 153:1534-1540.

Kruglyak L, Daly MJ, Reeve-Daly MP, Lander ES (1996): Parametric and nonparametric linkage analysis: A unified multipoint approach. Am J Hum Genet 58:1347-1363.

Kunugi H, Curtis D, Vallada HP, Nanko S, Powell JF, Murray RM, McGuffin P, Owen MJ, Gill M, Collier DA (1996): A linkage study of schizophrenia with DNA markers from chromosome 8p21-p22 in 25 multiplex families. Schizophr Res 22:61-68.

Lander E, Kruglyak L (1995): Genetic dissection of complex traits: Guidelines for interpreting and reporting linkage results. Nat Genet 11:241247.

Lipson A, Fagan K, Colley A, Colley P, Sholler G, Issacs D, Oates RK (1996): Velo-cardio-facial and partial DiGeorge phenotype in a child with interstitial deletion at 10p13-Implications for cytogenetics and molecular biology. Am J Med Genet 65:304-308.

Martin DL, Rimvall K (1993): Regulation of gamma-aminobutyric acid synthesis in the brain. J Neurochem 60:395-407.

Moises HW, Yang L, Kristbjarnarson H, Wiese C, Byerley W, Macciardi F, Arolt V, Blackwood D, Liu X, Sjogren B, Aschauer HN, Hwu H-G, Jang K, Livesley WJ, Kennedy JL, Zoega T, Ivarsson O, Bui M-T, Yu M-H, Havsteen B, Commenges D, Weissenbach J, Schwinger E, Gottesman IM, Pakstis AJ, Wetterberg L, Kidd KK, Helgason T (1995): An international two-stage genome-wide search for schizophrenia susceptibility genes. Nat Genet 11:321-324.

Mowry BJ, Nancarrow DJ, Lennon DP, Sandkuijl LA, Crowe RR, Silverman JM, Mohs RC, Siever LJ, Endicott J, Sharpe L, Walters MK Hayward NK, Levinson DF (1995): Schizophrenia susceptibility and chromosome 6p24-22. Nat Genet 11:233-234.
Nimgaonkar VL, Yang ZW, Zhang XR, Brar JS, Chakravarti A, Ganguli R (1995): Association study of schizophrenia and the IL-2 receptor beta chain gene. Am J Med Genet 60:448-451.

O’Donnell MC, Catts SV, Ward PB, Liebert B, Lloyd A, Wakefield D, McConaghy N (1996): Increased production of interleukin-2 (IL-2) but not soluble interleukin-2 receptors (sIL-2R) in unmedicated patients with schizophrenia and schizophreniform disorder. Psychiatry Res 65:171178 .

O'Hara BF, Andretic R, Heller HC, Cartert DB, Kilduff TS (1995): CABAA, CABAC, and NMDA receptor subunit expression in the suprachiasmatic nucleus and other brain regions. Brain Res Mol Brain Res 28: 239-250.

Pulver AE, Karayiorgou M, Lasseter VK, Wolyneic P, Kasch L, Antonarakis S, Housman D, Kazazian HH, Meyers D, Nestadt G, Ott J, Liang K-Y, Lamacz M, Thomas M, Childs B, Diehl SR, Wang S, Murphy B, Sun C, O'Neill FA, Nie L, Sham P, Burke J, Duke BW, Duke F, Kipps BR, Bray J, Hunt W, Shinkwin R, Nuallain MN, Su Y, MacLean CJ, Walsh D, Kendler KS, Gill M, Vallada H, Mant R, Asherson P, Collier D, Parfitt E, Roberts E, Nanko S, Walsh C, Daniels J, Murray R, McGuffin P, Owen M, Laurent C, Dumas J-B, d'Amato T, Jay M, Martinez M, Campion D, Mallet J (1994a): Follow-up of a report of a potential linkage for schizophrenia on chromosome 22q12-q13.1: Part 2. Am J Med Genet 54:44-50.

Pulver AE, Karayiorgou M, Wolyneic P, Lasseter VK, Kasch L, Nestadt G, Antonarakis S, Housman D, Kazazian HH, Meyers D, Ott J, Lamacz M, Liang K-Y, Hanfelt J, Ullrich G, DeMarchi N, Ramu E, McHugh PR, Adler L, Thomas M, Carpenter WT, Manschreck T, Gordon CT, Kimberland M, Babb R, Puck J, Childs B (1994b): Sequential strategy to identify a susceptibility gene for schizophrenia on chromosome 22q12q13.1 Part 1. Am J Med Genet 54:36-43.

Pulver AE, Lasseter VK, Kasch L, Wolyniec P, Nestadt G, Blouin JL, Kimberland M, Babb R, Vourlis S, Chen H, Lalioti M, Morris MA, Karayiorgou M, Ott J, Meyers D, Antonarakis SE, Housman D, Kazazian HH (1995): Schizophrenia: A genome scan targets chromosomes $3 p$ and $8 p$ as potential sites of susceptibility genes. Am J Med Genet 60:252-260.

S.A.G.E. (1994): "Statistical Analysis for Genetic Epidemiology, Release 2.2." Computer package available from the Department of Biometry and Genetics, LSU Medical Center, New Orleans.

Schizophrenia Collaborative Linkage Group (Chromosome 22) (1996): A combined analysis of D22S278 marker alleles in affected sib-pairs: Support for a susceptibility locus at chromosome 22q12. Am J Med Genet 67:40-45.

Schizophrenia Linkage Collaborative Group for Chromosomes 3, 6, and 8 (1996): Additional support for schizophrenia linkage on chromosomes 6 and 8: A multicenter study. Am J Med Genet 67:580-594.

Schwab SG, Albus M, Hallmayer J, Honig S, Borrmann M, Lichtermann D, Ebstein RP, Ackenheil M, Lerer B, Risch N, Maier W, Wildenauer DB (1995): Evaluation of a susceptibility gene for schizophrenia on chromosome $6 \mathrm{p}$ by multipoint affected sib-pair linkage analysis. Nat Genet 11:325-327.

Shprintzen RJ, Goldberg R, Golding-Kushner KJ, Marion RW (1992): Lateonset psychosis in the velo-cardio-facial syndrome. Am J Med Genet 42:141-142.

Straub RE, MacLean CJ, O’Neill FA, Burke J, Murphy B, Duke F, Shinkwin R, Webb BT, Zhang J, Walsh D, Kendler KS (1995): A potential vulnerability locus on schizophrenia on chromosome 6p24-22: Evidence for genetic heterogeneity. Nat Genet 11:287-293.

Straub RE, MacLean CJ, O’Neill FA, Walsh D, Kendler KS (1997): Genome scan for schizophrenia genes: A detailed progress report in an Irish cohort. Presented at: "World Congress of Psychiatric Genetics, Santa Fe, NM, USA."

Suarez BK, Hampe CL, Van Eerdewegh P (1994): Problems of replicating linkage claims in psychiatry. In Gershon ES, Cloninger CR, Barrett JE (eds): "Genetic Approaches in Mental Disorders." Washington, DC: American Psychiatric Press, pp 23-46.

Tatsumi M, Sasaki T, Sakai T, Kamijima K, Fukuda R, Kunugi H, Hattori M, Nanko S (1997): Genes for interleukin-2 receptor beta chain, interleukin-1 beta, and schizophrenia: No evidence for the association of linkage. Am J Med Genet 74:338-341.

Wang ZW, Black D, Andreasen NC, Crowe RR (1993): A linkage study of chromosome 11q in schizophrenia. Arch Gen Psychiatry 50:212-216. 